大氣環流力學 $の$ 数量的調查 $(2)^{*}$

榴 庭信一
\$1. 赫 帚
$\S 2$. 浾道環流の力學的智力消粍補充に就いて
\$3. マルグレス乾爆大氣偱環系としての赤道環流

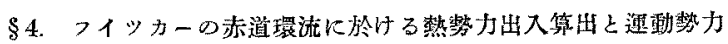

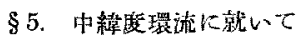
§6. 中絰度環流系に關する V. Bjerknes の模圆に就いて
§7. 結語 語

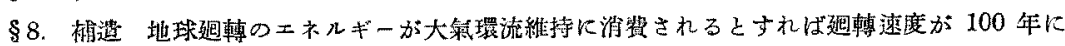 0.01〜2 秒尷れる程度で充分である.

\title{
§1、緒言
}

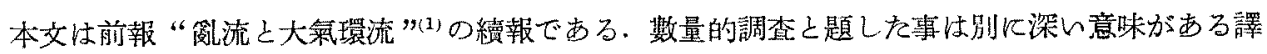
でなく,從來流澧力學の基本式から出發して實際現象を證明世んとして來え立場から少しく離れて， 勢力消耗，供給，環流系維持等に就いて大體その大きさを見皘つてみたに過ざい，只從來空氣の

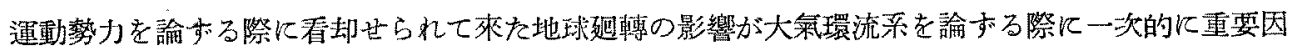
子をる事を强調しを事は特長と云へば特長上も云へよう.

\section{§2. 赤道環流の力學的勢力消耗補充に就いて}

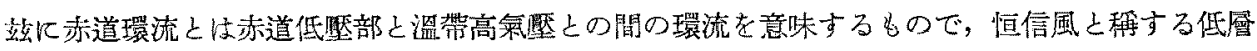

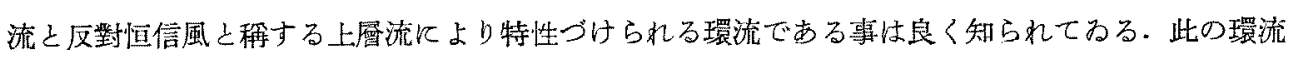
系は大氣環流三系の中で最も定常であるが今其の勢力維持に就いて簡單な教察を與へて見よう。

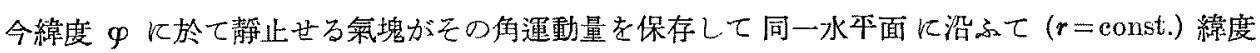
$\varphi^{\prime}$ に來をとする。

然らば繶度 $\varphi$ 几於ける解運動量 $Q$ は

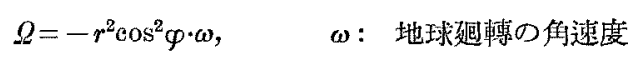

であり，絽度 $\varphi^{\prime}$ 亿於りる看運動量 $\Omega^{\prime}$ は

$$
Q^{\prime}=-r^{2} \cos ^{2} \varphi^{\prime}(\dot{\lambda}-\omega)
$$

である.此㞦を等题して

$$
\lambda=\omega\left[1-\frac{\cos ^{2} \varphi}{\cos ^{2} \varphi^{\prime}}\right]
$$

* S. Sakuraba: Some Quantitalive Studies on the General Circulation of the Atmosphere (2).

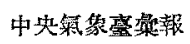

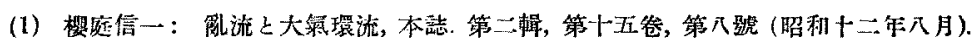


这に文は經度に沿ふ角分速度でする。然らば經度分力 $u$ は

$$
u=r \cos \varphi^{\prime} \cdot \dot{\lambda}=r \omega \frac{\cos ^{2} \varphi^{\prime}-\cos ^{2} \varphi}{\cos \varphi^{\prime}} .
$$

今此の式を用ひて緯度 $20^{\circ}$ に靜止せる氣塊が緯度 $10^{\circ}$ に移動したよすれば，東風 $41 \mathrm{~m} / \mathrm{sec}$. となる. 之は實際に考へられない程過大である。郎筆者が第 1 報で明らかれした樣に，角運動量は其の熦緯 度圈から緯度图に傳播世らる」ものではなく，途中に於て周圍の空氣之混合を起して角運動量の減 哀を招致するは明らかであるから，假りに今計算值の牛分を取つて東風 $20 \mathrm{~m} / \mathrm{sec}$ に相當する角運

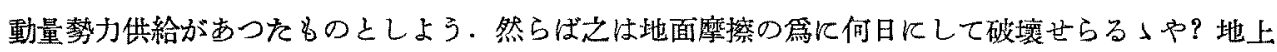
風速として上述の $20 \mathrm{~m} / \mathrm{sec}$ を探用する. 此札は無論過大沃失する算定でするが，計算の性質上斯 くの如く理想化された想定でも，大體の見當をつける分には差支へない。

\section{然らば表面摩擦は $\rho \kappa \nabla^{2}$ なる式に於て}

$$
\rho=10^{-3}, \quad \kappa=0.002, \quad V=2 \times 10^{3}
$$

とおいて 8 dyne $/ \mathrm{cm}^{2}$ を得る.

๘は R. C. Suteliffe の調查によつて $\kappa=0.004 〜 6$ を用ふべきであるが，之は高緯度で得を值で あり，赤道流は元來定常流で摩擦流を件ふ事が粆いからである.

抵面積 $1 \mathrm{~cm}^{2}$ の空氣垂直杜を考へ，その高さを $5 \mathrm{~km}$ ，風速を $20 \mathrm{~m} / \mathrm{sec}$.とすればその能率は

$$
10^{6} \mathrm{gm} . \mathrm{cm} / \mathrm{sec} \text {. }
$$

であり，從つて表面風は $\frac{1}{8} \times 10^{6}$ sec. にして破壞されて仕舞ふ.

從つて之を補っ篇に $10^{\circ}$ の緯度の間を角運動量を運搬するに要する速度は $I^{\circ}=111 \mathrm{~km}$ として

$$
\frac{110 \times 10^{6}}{\frac{1}{8} \times 10^{6}} \mathrm{~cm} / \mathrm{sec} \div 8.9 \mathrm{~m} / \mathrm{sec} \text {. }
$$

走得る。

茲に注意を要する點は, 現在の計算は D. Brunt, H. Jeffreys 等のものとは逢つて, 現在地上K 存在する風系が如何變形するかを目整上した計算でないから，風系の破壞される日數壮速き失 するのは止むを得ない。

以上極めて亂暴算定ではあるが，大體貿易風系の力學的勢力維持の數量的解決を把握し得えか 飞思多.

\section{§3、 マルグレス乾燥大氣循環系としての赤道環流}

前節の計算は單に貿易風系が力學的に維持出來る事を證明した丈けで，此の風系に熱的勢力が働 レてるない事を意味したのでは毛頭ない。

故爇力學的勢力關係を調查する意味で M. Margules の計算に做つて乾燥大氣之見做したる赤 


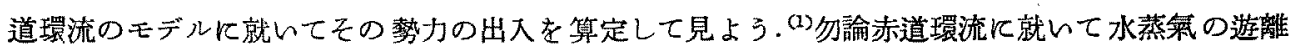
飞低る潜熱の供給を無視する事は頗る迂谴ではあるが，先づ此の樣な理想の場合を考究して見るの b無駄であるまい。第 1 圆就いて考へる.

第 1 圖

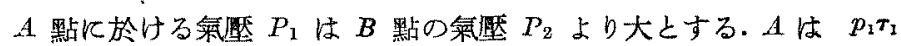
溫帶高氣壓に相賞する它ので $P_{1}=765 \mathrm{~mm}, T_{1}=293^{\circ} K$ (北半球, 夏季 Teneijffa K於ける氣溫) を探用する.

空氣は $A \rightarrow B$ に斷熱的に移野し，Bに於て熱の供給を受けて $T_{1}{ }^{\prime}$ より $T_{2}$ に昇溫する. $T_{2}$ は H. v. Ficker に倣つて $T_{2}=300^{\circ}$

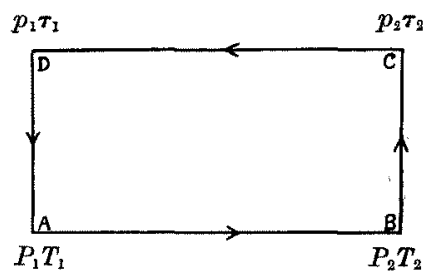
$K$ とおき, $P_{2}=755 \mathrm{~nm}$ を探用する. 之は大體赤道低壓部の氣壓示度である.

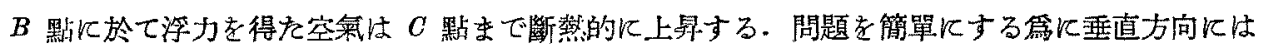
空氣は對流本衡の狀態に在るとする。從つて重力に逆つて第す仕事は無視されてある譯になる。 $C$ 點より $D$ 點に亦斷熱的に移動し， $C$ 點に於て渝却を受けて氣溫は $\tau_{2}^{\prime} よ り \tau_{1}$ に下降する. $D$ 點

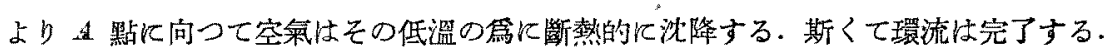

此の環流系に於ては，B於て $Q=C_{p}\left(T_{2}-T_{1}{ }^{\prime}\right)$ の熱量を賦與され, $D$ 亿於て $Q^{\prime}=C_{p}\left(\tau_{2}^{\prime}-\tau_{1}\right)$ の熱量の利脫を蒙る $Q-Q^{\prime}$ が仕事に變換した勢力であり,氣壓傾度を維持する仕事に外ならない.

去に $O_{p}$ 以宾氣の定壓比䓡で

$$
C_{p}=0.2375 \frac{\mathrm{Kal}}{\mathrm{kg} \operatorname{deg} 1 \mathrm{ee}}
$$

の數值を持つ.

乾燥空氣の测高公式

$$
\frac{p}{p_{0}}=\left(\frac{T_{0}-\alpha z}{T_{0}}\right)^{\frac{g}{R_{a}}}
$$

几於て

$$
\alpha=0.01 \mathrm{degr} \mathrm{ee} / \mathrm{m}, \quad R=29 \cdot 27 \mathrm{gm}^{2} \mathrm{sec}^{-2}
$$

を用ひて

$$
\begin{array}{ll}
\tau_{1}=211^{\circ} K, & p_{1}=249.18 \mathrm{~mm} \\
\tau_{2}=218^{\circ} K, & p_{2}=253.64 \mathrm{~mm}
\end{array}
$$

を得る。但し高さ $h$ としては Fieker の $h=8200 \mathrm{~m}$ を用るる。

及

$$
T_{1}^{\prime}=T_{1}\left(\frac{P_{2}}{P_{1}}\right)^{0.2884}, \quad \tau_{2}^{\prime}=\tau_{2}\left(\frac{p_{1}}{p_{2}}\right)^{0.2384}
$$

水よb

$$
T_{1}^{\prime}=291.89^{\circ} \mathrm{K}, \quad \tau_{2}^{\prime}=216.91^{\circ} \mathrm{K}
$$

となる。

斯くして

$$
Q=C_{p}\left(T_{2}-T_{1}^{\prime}\right)=8.11 C_{p}=1.92 \mathrm{Kal} / \mathrm{kg}
$$

(1) F. M. Exner: Dynamische Meteorologie, S. 169 (1925).

D. Brunt: Physical \& Dynamical Meteorology, p. 288 (1934). 


$$
Q^{\prime}=C_{p}\left(\tau_{2}^{\prime}-\tau_{1}\right)=5.91 C_{p}=1.40 \mathrm{Ka} / \mathrm{kg}
$$

となり，仕事に變換せる量として

$$
Q-Q^{\prime}=0.52 \mathrm{Kal} / \mathrm{kg}
$$

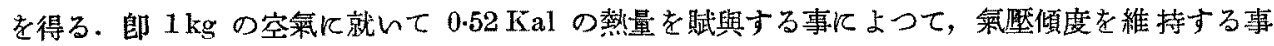
が出來る.

\section{\$4、フイッカーの赤道環流系に於ける熱勢力出入算出と運動勢力}

赤道環流系に於りる熱教力の出入に就いては古くは H.U.Sverdrup ${ }^{(1)}$ の浩翰㾂調查があり，最近

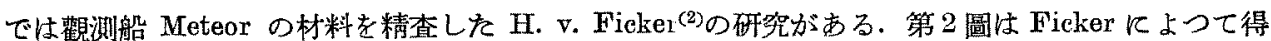
られた赤道環流の模圖である.

第 2 圖に於て， $T_{0}, q_{0}$ (比澋) は赤道に於ける值であり，

๑數值である.

$$
T_{0}=27^{\circ} \mathrm{C}, \quad q_{0}=18 \times 10^{-3}
$$

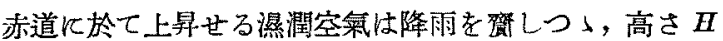
なる $T_{H}, q_{1}$ の所に達する.

氣塊は更に沈降しつ小北進し $D$ 點に洋する． $D$ は溫帶 高氣壓の發散の場所である。

空氣は咅に於て二派に別れ，一は上層を其の偤赤道に向

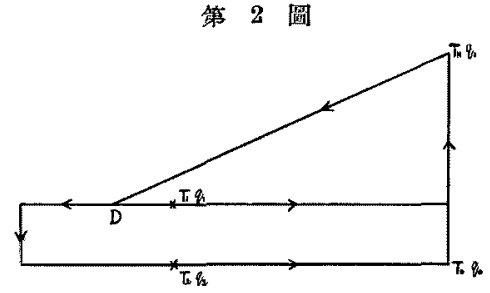

ふ氣流となり，之は高溫にして乾燥である。他は $D$ 點より更に若干北進しつ১下降して赤道に向

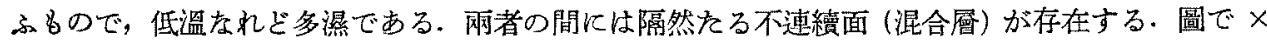
點で示したのは Teneriffa の Izano 觀湖所の位置で此所の萑澌では

$$
T_{2}=20^{\circ} \mathrm{C} \text { (夏) }, \quad q_{1}=3 \times 10^{-3}
$$

ごある。

此の偱環模圖によつて蓺の出入を算定する事は容易である.

郎熱の供給としては

$$
Q=r\left(q_{2}-q_{1}\right)+r\left(q_{0}-q_{2}\right)+C_{p}\left(T_{0}-T_{2}\right)=r\left(q_{0}-q_{1}\right)+C_{p}\left(T_{0}-T_{2}\right)
$$

であり，熱の逸散は

$$
Q^{\prime}=C_{p}\left(T_{1}^{\prime}-T_{1}\right)+C_{p}\left(T_{z}^{\prime}-T_{2}\right)
$$

で, 紋原

$$
T_{1}^{\prime}=T_{n}+\gamma(H-h), \quad T_{2}^{\prime}=T_{1}+\gamma h .
$$

蓯つて

$$
Q^{\prime}=C_{p}\left(T_{H}+\gamma H-T_{2}\right) \text {. }
$$

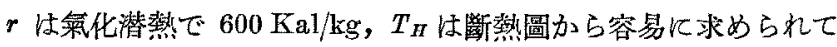

(1) H. U. Sverdrup : Der nordatlantjsche Passat, Veröff. d. Geophys. Inst., 2 (1917).

(2) H. v. Ficker: Bemerkung über den Wärmeumsatz innerhalb der Passatzirkulation, Sitz. Ber. Preuss. Aknd. Wiss., XI (1936). 


$$
H=8200 \mathrm{~m} \quad\left(T_{H}=-16^{\circ} \mathrm{C}\right) .
$$

$\gamma$ は断熱減率， $h$ は $T_{1}, q_{1}$ の高さである.

然らば

$$
Q=10.66 \mathrm{Kal} / \mathrm{kg}, \quad Q^{\prime}=9.33 \mathrm{Kal} / \mathrm{kg}
$$

を得る。

的熱勢力は $1 \mathrm{~kg}$ の空氣に就いて $1.33 \mathrm{Kal}$ の供給である事を知つた。

偖，吾々は前節に於て摩擦に依る，環流系の勢力㳙耗は角運動量の補給によつて說明出來る事を

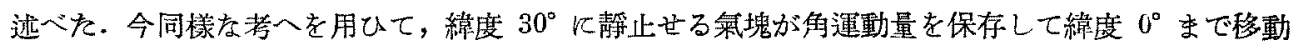
したとすれば勢力供給は速度東分の $100 \mathrm{~m} / \mathrm{sec}$ の增加を意味するから，1 kg の空氣に就いて

$$
\frac{1}{2} \times 10^{11} \mathrm{erg} / \mathrm{kg}^{\prime}=\frac{1}{2} \times 10^{4} \mathrm{joule} / \mathrm{kg}=5 \times 10^{3} \mathrm{joule} / \mathrm{kg}
$$

である.(1)

$$
\text { 熱等力供給は } \quad 1.33 \mathrm{Kal} / \mathrm{kg}=5.6 \times 10^{3} \mathrm{joule} / \mathrm{kg}
$$

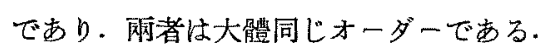

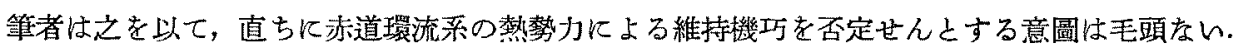
只大んさの上からは网者同一程度でする事に就いて，大方の注意を豀起せんとしたに外ならない。

\section{§5. 中緯慶環流に就いて}

中緯度環流はV. Bjerknes 其の他のノルウエー學派によつて早くから注目されて來た樣に特異 なる環流系を形成する。

師赤道環流は熱勢力が運動勢力反變㩊する環流系で，つまり熱エナーヂーが環流系を保持するも

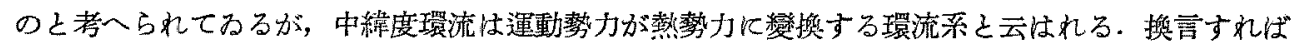
熱的勢力は中䋻度環流維持に働く勢力源であり得ない。

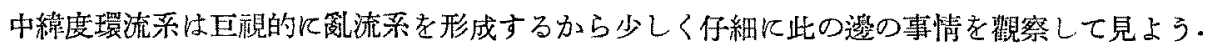

即此の系內に於ては氣㰮傾度と氣溫傾度とが同一方向をとる事である.此の場合氣壓度傾は相堂 の厚みを以て保持されるものである。

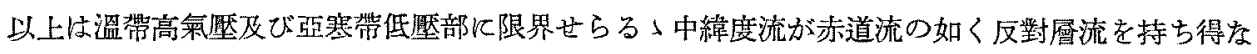
レ理由である。

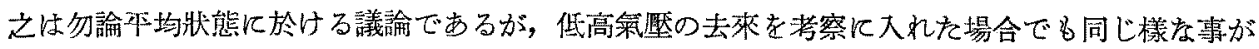
云へる.

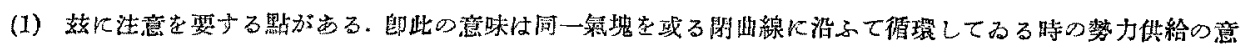

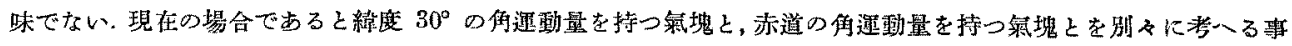

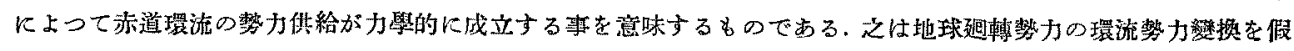

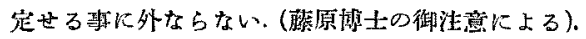




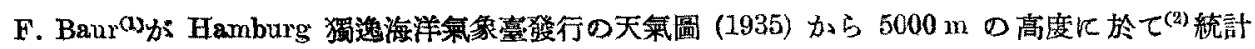
した結果によると，458 の高氣壓（相對的高氣壓をる含む）の中

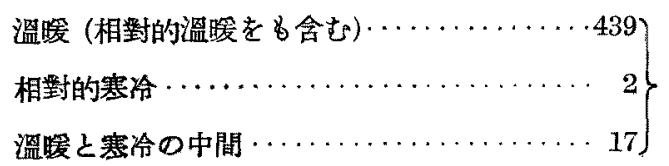

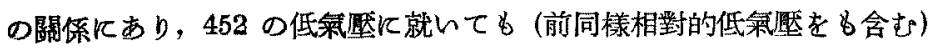

寒冷 (相對的寒冷

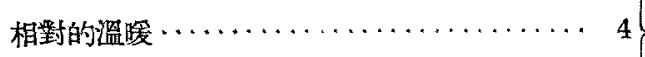

寒冾之溫暖之の中間 $\ldots \ldots \ldots \ldots \ldots \ldots \ldots \ldots \ldots$

の割合である・

之は氣壓傾度之氣溫傾度が擾锍の狀態に於ても同一方向を保持する事を證明する有力なる統計で ある. 此の結果を立場を變へて觀察すれば, $5000 \mathrm{~m}$ (2)の高度の氣壓分布は圈界面附近の夫れを代表

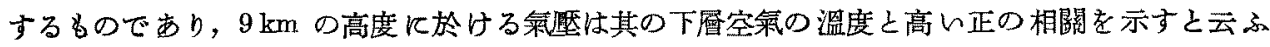
Dines 及び Sehedler の統計を更に一般化しをものに外ならない。

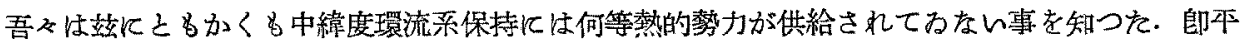

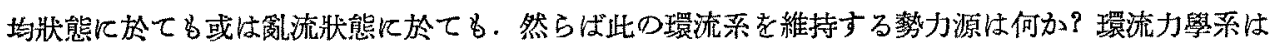

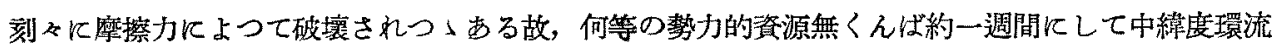
は消失するならんとは H. Jeffreys の豫想せし所である。

筆者は前報に於て低氣涯に依る地球迴轉のエナージー（角運動量の形式により）の運搬によつて 此の缺陊を補ひ得る事を登明した。 之は H. Jeffreys の定性的證明を定量的飞進展せしめを如く一 見考一られるが，彼の考へとは根本的に異る事は原文を鉒して明らかである。つまりJeffreys は

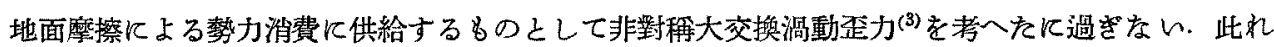

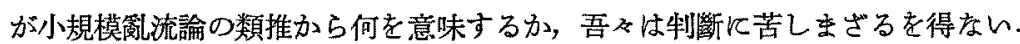

\section{§6. 中繶度環流采に關するマ. Bjerknes の模圖に就いて}

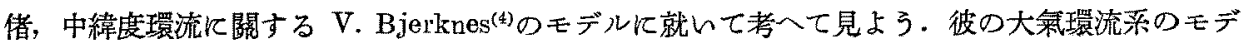
ルの中，赤道環流及び高緯度環流に就いては問題が無い，之等の場合には氣壓傾度と氣溫傾度が同

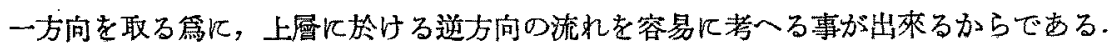

(1) F. Baur: Die Bedeutung der Stratosphäre für die Grosswetterlage, Met.|Zeit. 1936, S. 239-247.

(2) 筑密には 5000 Berk.

(3) 大交換とは Grosse Austausch の譯で, Jeffreys は此の機跨に就いては何等言及する所は無いが.

(4) V. Bjerknes: On the Dynamies of the Circular Vortex with Applications to the Atmosphere and Atmospheric Vortex and Wave Motions, Geof. Pub., 2 (1921). 
中紿度環流系に就いては事情が可成り異つて, 氣壓傾度と氣溫傾度とは同一方向を取る, 故に上 層に於ける平面內の回歸流が考へにくい事で击り, 從つて V. Bjerknes の模圖は此の意味に於い て再檢徱の必要がある.

先づ中緯度環流系中の下層流である.之は或は摩擦流によつて說明出來上う. 即環流系は溫帶高

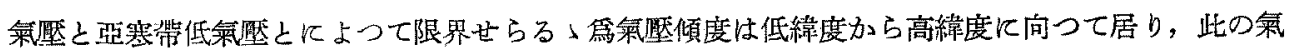
壓傾度に對應する傾度風からの偏差流丈けが子午面流として現出しょう。但し之は $1 \mathrm{~km}$ 以下の低 層飞限られるた゚らう事付容易に相像出來る。

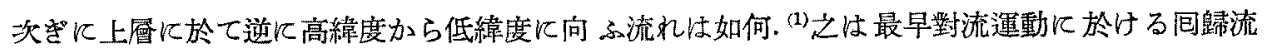

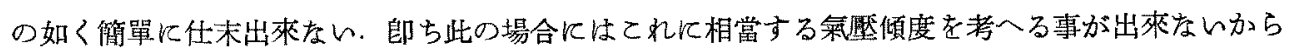
でする．但し，外の方面からの說明が出來ない譯でもない.

今吹式に於て

$$
\frac{D u}{D t}=-\frac{1}{\rho} \frac{\partial p}{\partial x}+l v+K \frac{\partial^{2} u}{\partial z^{2}}, \quad \frac{D v}{D t}=-\frac{1}{\rho} \frac{\partial p}{\partial y}-l u+K \frac{\partial^{2} v}{\partial z^{2}},
$$

$x$ 軸を南に, $y$ 軸を東にとり

$$
u=\bar{u}+u^{\prime}, \quad v=\bar{v}+v^{\prime}
$$

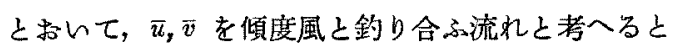

$$
\frac{D u^{\prime}}{D t}=l v^{\prime}+K \frac{\partial^{2} \bar{u}}{\partial z^{2}}, \quad \frac{D v^{\prime}}{D t}=-l u^{\prime}+K \frac{\partial^{2} \bar{v}}{\partial z^{2}}
$$

となり， $\frac{D u^{\prime}}{D t}$ 及び $\frac{D v^{\prime}}{D t}$ を三次の微少量と考へて之を省略すれば

$$
\frac{\partial^{2} \vec{v}}{\partial z^{2}}=5 \times 10^{-9} \mathrm{~cm}^{-1} \mathrm{sec}^{-1}, \quad K=10^{5} \mathrm{~cm}^{2} \mathrm{sec}^{-1(2)}
$$

のときには緯度 $50^{\circ}$ に於て

$$
u^{\prime}=0.04 \mathrm{~m} / \mathrm{sec} \text {. }
$$

を得る.師 $\frac{\partial^{2} \bar{v}}{\partial z^{2}}$ が正である時は地球司轉の轉向力に依つて子午面南分流 $4 \mathrm{~cm} / \mathrm{sec}$ が 理論的に祸 想される.

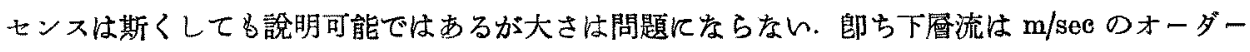
であるからである。

次ぎに勢力傳播の立場からは如上の V. Bjerknes の模圖は全然意味がない. 郎ち中緯度環流系 を保持する源動力は角運動量の傳播以外には考人難く, 然か子その移動のセンスは全くV. Bjerk-

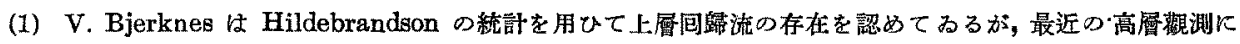
徽して之は首肯し難い事である。

(2) O. K. M. Douglas: A Problem of the General Circulation, Q. J. Roy. Met. Soc., 57 (1981). 
nes の夫れとは反對である。

斯くして吾みは必然的に次の結論に到達する，中緯度環流系は他の環流系とは特異なる存在であ り，此の點では吾ねはV. Bjerknes の考々一致する. 但し中緯度環流系が，運動勢力を熱勢力に 變換する場であり，從つて勢力の消費系であると結論する（變撸せる熱勢力が運動のエナーヂーを 再供給する機巧は熱力學的效率の見地からも考へにくい).V. Bjerknes の意見には吾ふは必市し タ濽意を表さをいるのである、つまり吾々の豫想によれば中緯度環流の力學的勢力は，及之を力學 的に補古する事が出來るからである。

\section{§7. 結語}

從來或る系內に於ける空氣の運動勢力を論和る際に於ては，地球伵轉の影響は單に運動の向をを 變へる丈けに過ぎ市，勢力そのものには無閶係として取り报はれて來を 之は確かに小規模の現策 を論ずる限りに於て正しい見解である。低氣暨諭其他が斯くして論議を進めて來たのは當然である。 然し大氣環流系の如き大規模の空氣の交鲃を取扱ふ場合に於ては，地球趣轉の影響は環流系の勢

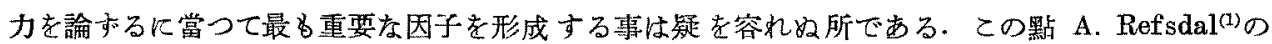
大氣熱力論は，大氮環流系への應用に閺する限 り或程度の修整を必要とする譯でする.

此の考は中緯度環流系もとより然り，從來熱的勢力の供給のみと考へられて來を赤道環流系沉

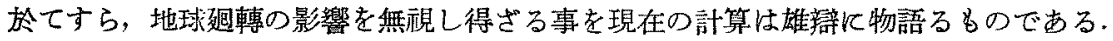

終りにのぞんで終始御指導を仰いでるる萦長岡田先生，此の小文の主旨に就いて真摰なる御注意

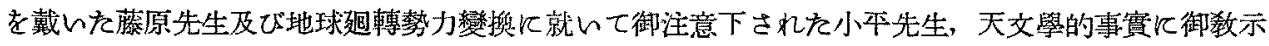
下された川畑先生に心からの感謝の意を表する次第である。

(昭和十二年九月下旬)

\section{§8. 補遺 地球迥轉のエネルギーと大氣環流のエネルギー(2)}

吾々は前節に於て，從來諸家の研究に看却されて來を地球超轉のエネルギーが如何に大氣環流勢

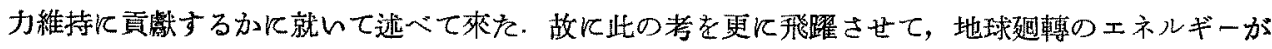
その篮大氧環勢力消耗補冭に費ひやされたら何年現狀を維持し得るかに就いて簡單な計算を施して 見よう.

牛徑 $a$ の球が $\omega$ なる角速度で迴轉せるときの運動勢力は

である・

$$
K \cdot E=\frac{4}{15} \pi \rho a^{6} \omega^{2}
$$

竝化

とおけば

$$
\begin{gathered}
\rho=5.5 \quad a=6.4 \times 10^{8} \quad \omega=0.7 \times 10^{-4} \\
K \cdot E=2.42 \times 10^{36} \text { ergs. }
\end{gathered}
$$

(1) A. Refadal: Zur Thermodynamik der. Atmosphäre, Geof. Pub.. 9 (1932).

（2）此の編小平博士の御注意に上る. 
を得る。

偖大氣環流系の浻耗勢力は D. Brunt 飞低れば $5 \times 10^{7}$ ergs per $\mathrm{m}^{2}$ per sec.(1)

であるから，地球の全表面に就いては（表面積を約 $5 \cdot 14 \times 10^{12} \mathrm{~m}^{2}$ とおいて）

$$
2.57 \times 10^{20} \cdot \mathrm{ergs} / \mathrm{sec}^{(2)}
$$

得る。 ${ }^{(3)}$

從つて地球趣轉の勢力は摩擦消耗の爲に

$$
\frac{2.42 \times 10^{38}}{2.57 \times 10^{20}} \mathrm{see} \div 10^{16} \mathrm{sec}
$$

にして破壞される.

一年は約 $3.15 \times 10^{7} \mathrm{sec}$ であるから

$$
10^{16} \mathrm{sec} \div \frac{1}{3} \times 10^{9} \text { years }
$$

に相當する.

今 100 年に地球の趣轉が $0.01 \mathrm{sec}$ 宛々遲れるとせば 1 日遲れる爲には 864000,000 年

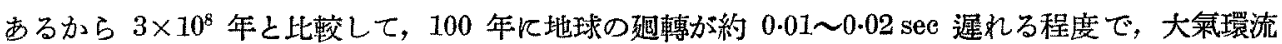
の勢力を補充する事が出來る事を知る．之は天文學的觀測事實に微しても決して抵觸しない.

\section{大阪灣に於ける津浪に就て (第一報)}

廣 野 卓 藏

緒論

大阪市は大阪灣の奧部に在りて之に隐み灣沿岸の最重要をる位置を占めて居る.併し乍ら古來此の 地はしばしば津浪或は高潮に閔はれその都度非常な奖害を被つて來を。此等過去に於ける津浪或は

(1) D. Brunt: Physical \& Dynamical Meteorology, p. 278 (1934).

（2）D. Brunt の計笋は高緯度の摩擦消費の最大の所でするから，之を全地球面に演釋する事は消費勢力を 過大に見積る承を害味する。

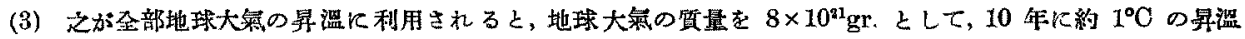
を境味する。

* T. Hirono: Tunami Wave in Osaka Bay (I). 